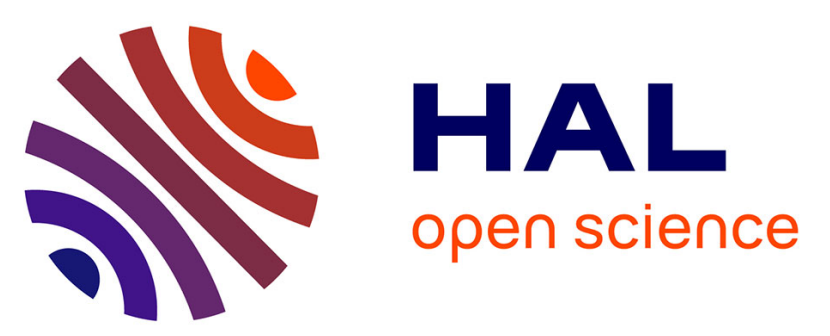

\title{
Comparison between the mechanical behavior of the human healthy AA and commercial prostheses under various mechanical loadings
}

Audrey Lemercier, Lucie Bailly, Christian Geindreau, Mamadou Toungara, Pierre Latil, Laurent Orgéas, Valérie Deplano, Nadège Boucard

\section{To cite this version:}

Audrey Lemercier, Lucie Bailly, Christian Geindreau, Mamadou Toungara, Pierre Latil, et al.. Comparison between the mechanical behavior of the human healthy AA and commercial prostheses under various mechanical loadings. 38th Congress of the Societe de Biomecanique, 2013, Marseille, France. pp.315-317, 10.1080/10255842.2013.815930 . hal-00924984

\section{HAL Id: hal-00924984 \\ https://hal.science/hal-00924984}

Submitted on 7 Jan 2014

HAL is a multi-disciplinary open access archive for the deposit and dissemination of scientific research documents, whether they are published or not. The documents may come from teaching and research institutions in France or abroad, or from public or private research centers.
L'archive ouverte pluridisciplinaire HAL, est destinée au dépôt et à la diffusion de documents scientifiques de niveau recherche, publiés ou non, émanant des établissements d'enseignement et de recherche français ou étrangers, des laboratoires publics ou privés. 


\title{
Comparison between the mechanical behavior of the human healthy AA and commercial prostheses under various mechanical loadings
}

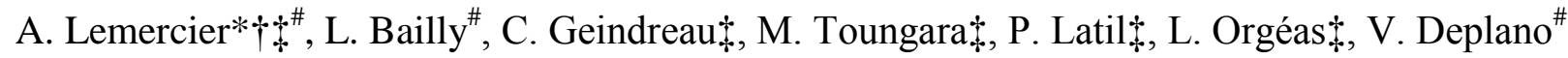 \\ and N. Boucard $\dagger$ \\ † MDB Texinov, 38354, La Tour du Pin, France \\ 千 CNRS/Univ Grenoble Alpes, Laboratoire 3SR BP 53,38041 Grenoble cedex 9, France \\ ${ }^{\#}$ CNRS, Aix-Marseille Univ, IRPHE, 13384, Marseille, France
}

Keywords: AA; Textile prosthesis; Multiaxial tensile tests; Bending; Inflation.

\section{Introduction}

Standard chirurgical treatment of abdominal aortic aneurysm (AAA) involves the placement of tubular synthetic aortic prostheses. Most of these implants are made up of polyester textiles or porous expanded polytetrafluoroethylene. Normalized tests are dedicated to their assessment (ISO7198:1998). However, such experiments are not sufficient to characterize the complete mechanical performance of these implants (Le Magnen et al., 2001) and to ensure their mechanical compatibility with the host artery. Thus, the design of mechanically compatible vascular prostheses still remains a challenge. Within this context, a full comparison of the mechanical behavior of the human healthy abdominal aorta (AA) with commercial prostheses is proposed. An original numerical database on the mechanical behavior of human AA subjected to various mechanical loadings is first built and then compared with experimental data obtained from mechanical tests performed on prostheses.

\section{Methods}

AA mechanical model. A two-layer model based on the $\rho$-model (Holzapfel and Ogden, 2010) was chosen to describe the anisotropic hyperelastic AA behavior. The volumetric strain-energy function is written $W=W_{\text {iso }}+W_{m}+W_{a}, W_{\text {iso }}=0.5 c_{1}\left(I_{1}-\right.$ 3 ) is the isotropic contribution, $c_{1}$ being a material parameter, and $I_{1}$ the first invariant of the right Cauchy-Green tensor. Functions $W_{m}$ and $W_{a}$ are the anisotropic contributions of the two-fibre families in the media and the adventitia:

$W_{i}=\frac{k_{1}^{i}}{k_{2}^{i}}\left\{e^{k_{2}^{i}\left[(1-\rho)\left(I_{1}-3\right)^{2}+\rho\left(I_{4}^{i}-1\right)^{2}\right]}-1\right\}, i \in\{m, a\}$, where $k_{1}^{i}, k_{2}^{i}$ denote the fibres material parameters, $\rho \in[0,1]$ is a measure of the AA anisotropy, and where $I_{4}^{i}$ are invariants depending on the angle between fibers in each layer $\theta_{0}^{i}$. These 8 material parameters adjusted (see Figure 1(a,b)) with the biaxial tensile data reported by Vande Geest (2005) are reported in Table 1, for a group of donors less than 30 years old (Gr.1), between 30 and 60 years old (Gr.2) and over 60 years old (Gr.3).
Numerical simulations. The AA model was implemented in a finite element code (Comsol Multiphysics $^{\text {TM } 3.5 a) . ~ P l a n a r ~ u n i a x i a l ~ o r ~ b i a x i a l ~ t e s t s ~}$ were simulated on planar AA square (20mm width) specimens. Various tension ratios $\mathrm{T}_{\theta \theta}: \mathrm{T}_{11}$ were used, i.e. $0: 1,0.5: 1,0.75: 1,1: 1,1: 0.75,1: 0.5$ and $1: 0$, the tests being stopped when the highest tension reached $120 \mathrm{~N} \cdot \mathrm{m}^{-1}$. Cantilever bending tests of slender strips of AAs under their own weight were simulated on similar samples. Cantilever bending tests were simulated on a representative AA geometry, i.e. a tube of $20 \mathrm{~mm}$ inner diameter and $50 \mathrm{~mm}$ long. Finally, inflations of the AA geometry with an internal pressure varying from 0 to 160 $\mathrm{mmHg}$ were simulated for several values of axial prestretch of the AA $\left(\lambda_{l l}=1\right.$ to 1.2$)$. The Peterson modulus $E_{P}$ could thus be deduced from these simulations in the pressure range $80-120 \mathrm{mmHg}$.

\begin{tabular}{|c|c|c|c|c|c|c|c|c|}
\hline & $\begin{array}{c}c_{1} \\
(\mathrm{kPa})\end{array}$ & $\begin{array}{c}k_{1}^{m} \\
(\mathrm{kPa})\end{array}$ & $\begin{array}{c}k_{2}^{m} \\
(-)\end{array}$ & $\begin{array}{c}\theta_{0}^{m} \\
\left({ }^{\circ}\right)\end{array}$ & $\begin{array}{c}k_{1}^{a} \\
(\mathrm{kPa})\end{array}$ & $\begin{array}{c}k_{2}^{a} \\
(-)\end{array}$ & $\begin{array}{c}\theta_{0}^{a} \\
\left({ }^{\circ}\right)\end{array}$ & $\begin{array}{c}\rho \\
(-)\end{array}$ \\
\hline 1 & 13.6 & 3.3 & 0.2 & 0.5 & 3.9 & 0.5 & 88.8 & 0.7 \\
\hline 2 & 1.0 & 30.2 & 59.3 & 19.2 & 29.6 & 30.1 & 59.3 & 0.4 \\
\hline 3 & 3.1 & 41.1 & 32.0 & 4.0 & 26.8 & 49.1 & 77.7 & 0.2 \\
\hline
\end{tabular}

Table 1 Optimized parameters of the AA model. Prostheses mechanics. Two aortic textile prostheses were selected, showing either a woven $\left(\mathrm{P}_{1}\right)$ or a knitted $\left(\mathrm{P}_{2}\right)$ structure. Both prostheses were characterized by a severe longitudinal crimping. Each tissue was solely subjected to stretch-controlled uniaxial tests, performed at a stretch rate of $10^{-2} \mathrm{~s}^{-1}$ thanks to a tensile device (ElectroForce ${ }^{\circledR}$, Bose Corporation, max load $400 \mathrm{~N})$. Both bending and inflation tests were conducted using mechanical conditions similar to the ones applied in numerical simulations. All tests were combined to video recordings (Nikon CCD video camera $7360 \times 4912 \mathrm{px})$ of the tube's initial and deformed shapes (Figure 2(a)). After bending tests, vertical and horizontal displacements of the tube centerline were extracted from the recorded images. During the inflation tests, the target axial prestretches were achieved by controlling the crimping deployment. Afterwards, the diameter variations of each prosthesis were detected from the images and the Peterson modulus $\mathrm{E}_{\mathrm{p}}$ was estimated. 


\section{Results and Discussion}

Numerical results obtained for the Gr.2 AAs are presented on Figure 1. Figure 1 $(\mathrm{a}, \mathrm{b})$ proves the good agreement between the adjusted AA model and experimental results of Vande Geest. The two simulated tensile tests plotted in Figure 1(a,b,c), clearly underline the anisotropic mechanical behavior of the healthy aortic tissue. Figure 1(d) depicts the bending of an AA slender strip under its own weight, in both the longitudinal and orthoradial direction. By contrast to previous results, such mechanical response is weakly influenced by the anisotropy of the AA wall. Due to the anisotropy of the AA wall, $\mathrm{E}_{\mathrm{P}}$ decreases while increasing the axial prestretch, see Figure 1(e). Finally, Figure 1(f) shows the vertical displacement of the AA centerline during a cantilever bending test. Notice that similar trends have been observed in the case of Gr.1 and Gr.3. However, if the mechanical responses of the Gr.2 and Gr.3 AAs are quite similar, they are much stiffer than the ones for the Gr.1 for planar biaxial and inflation tests. Surprisingly, our results also showed that this trend is reverted in the case of bending tests at both the tissue or aorta scale. These results must be confirmed by developing similar experiments. Figure 2(a) shows an example of a bending test on $\mathrm{P}_{1}$. Figure 2(b) depicts the evolution of the vertical displacement versus the axial position. The mean difference between the prostheses and the Gr.2's AA results is $13.9 \%$ for $\mathrm{P}_{1}$ and $8.8 \%$ for $\mathrm{P}_{2}$. Figure 2(c) illustrates an experimental inflation test performed on $\mathrm{P}_{2}$. Pressure-diameter curves are displayed in Figure 2(d) for axial prestretch $\lambda_{11}=1$ and 1.2. The average $E_{p}$ was assessed to $493 \mathrm{kPa}$ and $1406 \mathrm{kPa}$ respectively. By contrast to the AA, our experimental results showed that this modulus increases while increasing the axial stretch. The actual longitudinal crimping of vascular prostheses clearly increases their bending rigidities, which are similar to the ones of the AAs. However, this crimping may also lead to strong variations of prostheses' $E_{\mathrm{P}}$ with the axial prestretch.

\section{Conclusions}

A comparison between the mechanical behavior of the AA and prostheses under various mechanical loadings was performed. Bending tests and inflation tests have been also performed. The results showed that the prosthesis' crimping plays an important role on its mechanical behavior, this crimping can help or not at reproducing the mechanical behavior of AA. Moreover, uniaxial tests on textiles, not presented here, have shown that they are much stiffer than AA tissue in both longitudinal and orthoradial direction and that their anisotropic behavior remains very far from that of the host artery. All these results point out that the actual prostheses are not fully mechanically compatible with the host aorta.
Acknowledgments: The authors would like to thank the ANRT for financial support.
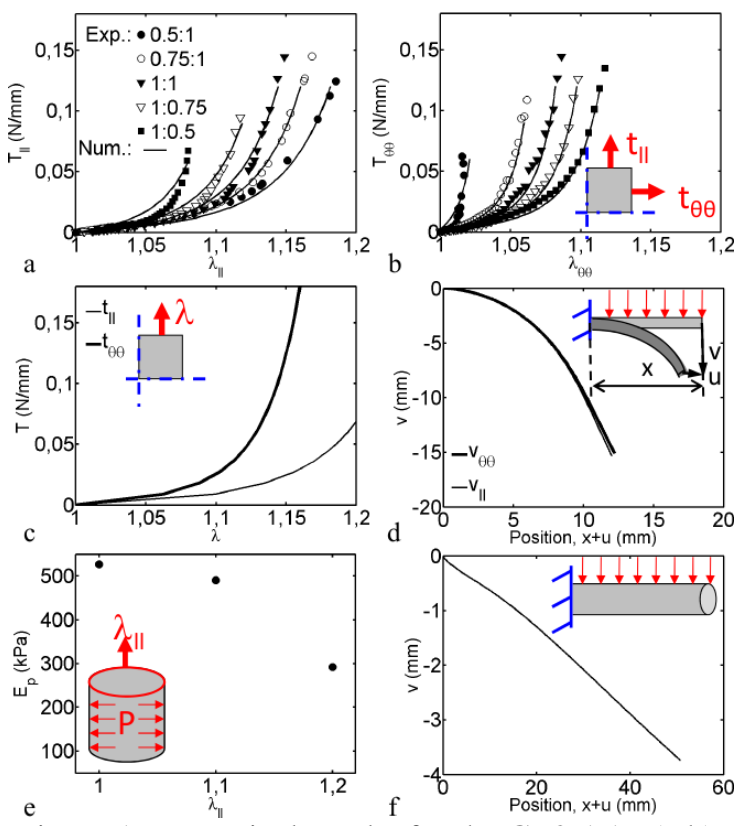

Figure 1: Numerical results for the Gr.2 AAs $(a, b)$ :

Biaxial tensile tests vs Vande Geest's data (marks)

(c) uniaxial tensile tests (d) tissue sample bending test (e) Peterson modulus (f) tube bending test: displacement versus axial position.
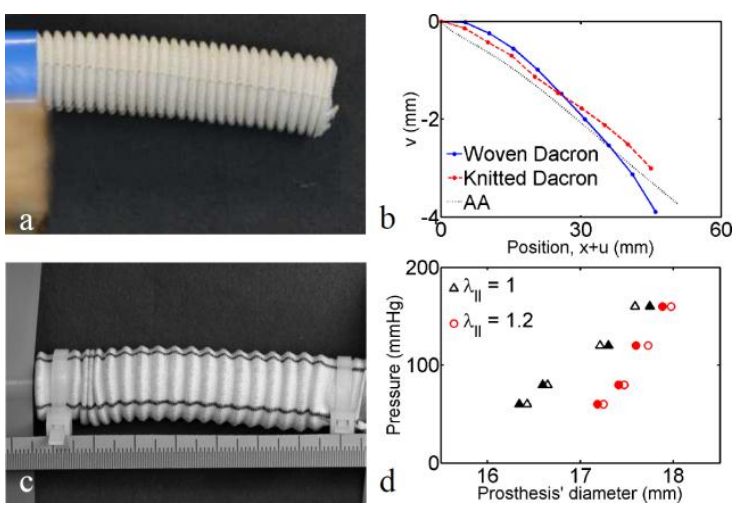

Figure 2: (a) Bending test on prosthesis $\mathrm{P}_{1}$ (b) Experimental and numerical results: displacement vs position. (c) Inflation test on $\mathrm{P}_{2}$ (d) Experimental pressure-diameter variations.

\section{References}

Holzapfel GA, Ogden RW. 2010. Constitutive modelling of arteries. Proceedings of the Royal Society. A 466(2118):1551- 1597.

ISO 7198:1998. Cardiovascular implants, Tubular vascular prostheses.

Le Magnen JF, Mathieu D, Chakfé N, Durand B. 2001. Approche critique des tests normalisés. Acquisitions Nouvelles sur les Biomatériaux Vasculaires. 13-30.

Vande Geest JP. 2005. Towards an improved rupture potential index for abdominal aortic aneurysms. PhD thesis. University of Pittsburgh. 